\title{
Recruitment of Casein Kinase 2 is Involved in A $\beta$ PP Processing Following Cholinergic Stimulation
}

\author{
Silvia C. Lenzken ${ }^{1}$, Serena Stanga, Cristina Lanni, Fabio De Leonardis ${ }^{2}$, Stefano Govoni and \\ Marco Racchi* \\ Department of Experimental and Applied Pharmacology, Centre of Excellence in Applied Biology, University of \\ Pavia, Pavia, Italy
}

Accepted 2 February 2010

\begin{abstract}
The amyloid- $\beta$ protein precursor $(\mathrm{A} \beta \mathrm{PP})$ is an integral membrane protein subjected to constitutive and regulated proteolytic processing. We have previously demonstrated that protein kinase $\mathrm{C} \varepsilon(\mathrm{PKC} \varepsilon)$ plays a key role in the regulation of $\mathrm{A} \beta \mathrm{PP}$ metabolism via cholinergic receptors. The purpose of the present work is to clarify whether other putative signaling systems are involved in the same pharmacological pathway. We focused particularly on casein kinase 2 (CK2), demonstrating a direct interaction between $\mathrm{PKC} \varepsilon$ and CK2 following cholinergic stimulation. Treatment of human neuroblastoma SH-SY5Y cells with a selective inhibitor of $\mathrm{CK} 2$ reduced the effect of carbachol on the release of $\mathrm{sA} \beta \mathrm{PP} \alpha$. This treatment did not influence the activation and translocation of $\mathrm{PKC} \varepsilon$ suggesting that the latter is located upstream of CK2. On the basis of our results, we add another player to the complex cellular mechanisms regulating non-amyloidogenic processing of $\mathrm{A} \beta \mathrm{PP}$.
\end{abstract}

Keywords: Alzheimer's disease, amyloid- $\beta$ protein precursor, casein kinase 2, cholingergic, neuroblastoma, protein kinase C. signal transduction

\section{INTRODUCTION}

Alzheimer's disease (AD) is characterized by deposition in the brain of fibrillar aggregates of a peptide named amyloid- $\beta(\mathrm{A} \beta)$, derived from proteolytic processing of a larger precursor called the amyloid- $\beta$ protein precursor $(\mathrm{A} \beta \mathrm{PP})[1]$.

$\mathrm{A} \beta \mathrm{PP}$ is an integral membrane protein with a complex proteolytic metabolism that can be simplified in a so called "non amyloidogenic" pathway, based on

\footnotetext{
${ }^{1}$ Present affiliation: Department of Biotechnology and Biosciences, University of Milano Bicocca, Milano, Italy.

${ }^{2}$ Present affiliation: Department of Biochemistry "A. Castellani", University of Pavia, Pavia, Italy.

*Correspondence to: Marco Racchi, Dept. of Experimental and Applied Pharmacology, University of Pavia, Viale Taramelli 14 27100 Pavia, Italy. Tel.: +39 0382 987738; Fax: +39 0382 987405;
} E-mail: racchi@unipv.it. the action of $\alpha$-secretases cleaving $\mathrm{A} \beta \mathrm{PP}$ inside the $\mathrm{A} \beta$ region producing a soluble fragment $\mathrm{s} \beta \mathrm{PP} \alpha$, thus precluding $\mathrm{A} \beta$ production, and in the "amyloidogenic" pathway, based on the activities known as $\beta$ - and $\gamma$ secretase, which generates $\mathrm{A} \beta[2]$.

The most studied proteases involved in $\alpha$-A $\beta$ PP processing are TNF $\alpha$ converting enzyme (TACE; ADAM17) [3] and ADAM10 [4,5]. Interestingly, while TACE seems to be involved in the phorbol esters-mediated release of $\operatorname{sA} \beta \operatorname{PP} \alpha, \operatorname{ADAM} 10$ has been shown to be involved in both the regulated and constitutive secretion of $\mathrm{A} \beta \mathrm{PP}[6]$.

A $\beta$ PP processing by $\alpha$-secretase occurs via a constitutive pathway and by receptor mediated activation of multiple signal transduction pathways among which protein kinase $\mathrm{C}(\mathrm{PKC})$ is a major player $[7,8]$. Among others, cholinergic receptors (mAChR) conduce to an increase in the release of soluble $\mathrm{N}$-terminal $\mathrm{A} \beta \mathrm{PP}$ 
derivates [9], and this has been the basis of numerous studies that demonstrated that acetylcholinesterase inhibitors may influence the non amyloidogenic processing of $\mathrm{A} \beta \mathrm{PP}[10-12]$.

We have previously demonstrated that $\mathrm{PKC} \varepsilon$, among other kinase isoforms, is specifically involved in cholinergic-mediated $\mathrm{A} \beta \mathrm{PP}$ processing [13], however, the exact target of PKC phosphorylation related to $\mathrm{A} \beta \mathrm{PP}$ processing is still elusive. Several observations in the literature suggest that activation of $\mathrm{A} \beta \mathrm{PP}$ cleavage/release by PKC involves phosphorylation/interaction with some still unknown components of the processing pathway.

We turned our attention to casein kinase 2 (CK2), an ubiquitous and essential serine/threonine protein kinase, found in eukaryotic cells, with a list of more than 300 known protein substrates [14]. It has traditionally been classified as a stable tetrameric complex consisting of two catalytic subunits, $\alpha$ or $\alpha^{\prime}$, and two regulatory subunits $\beta$. The actual occurrence of the three predicted tetramers, $\alpha 2 \beta 2, \alpha \alpha^{\prime} \beta 2$, and $\alpha^{\prime} 2 \beta 2$, has been well documented [15]. Interestingly, some reports have suggested that CK2 could be activated by PKC [1618]. Consequently, we inquired the possibility of a CK2 participation in the $\mathrm{s} \beta \mathrm{PP} \alpha$ release downstream of cholinergic stimulation.

\section{MATERIALS AND METHODS}

\section{Materials and chemicals}

All culture media, supplements, and fetal calf serum (FCS) were obtained from Euroclone (Life Science Division, Milan, Italy). Electrophoresis reagents were obtained from Bio-Rad (Hercules, CA, USA), PULSin TM was purchased from Polyplus-transfection SA (Ilkirch, France) and the inhibitor peptide of $\mathrm{PKC} \varepsilon$ translocation was purchased from Calbiochem (EMD Chemical Inc., San Diego, CA, USA). All other reagents were purchased from Sigma Chemical Co. (St. Louis, MO, USA). Carbachol was dissolved in PBS and then diluted in serum free medium to working concentrations at the time of use; inhibitor peptide (IP) of $\mathrm{PKC} \varepsilon$ translocation was dissolved in PBS and stored at $-20^{\circ} \mathrm{C}$ and 4,5,6,7-tetrabromobenzotriazole (TBB) was dissolved in DMSO and stored at $4^{\circ} \mathrm{C}$. Stocks were diluted in serum-free medium to working concentration at the moment of use.

\section{Cell cultures}

The human neuroblastoma SH-SY5Y cell line from European Collection of Cell Cultures (ECACC No. 94030304) was used for these experiments. SH-SY5Y cells were cultured in medium with equal amount of Eagle's minimum essential medium and Nutrient Mixture Ham's F-12, supplemented with $10 \%$ FCS, 2 mM glutamine, $100 \mathrm{U} / \mathrm{ml}$ penicillin, $100 \mu \mathrm{M}$ streptomycin, $1 \%$ non-essential aminoacids at $37^{\circ} \mathrm{C}$ in $5 \% \mathrm{CO}_{2}$. Cells were plated at a density of $1 \times 10^{5}$ cells $/ \mathrm{cm}^{2}$, and treatments were performed after $24 \mathrm{~h}$ from seeding. Overexpressing $\mathrm{PKC} \varepsilon$ cells were obtained by transfection of the plasmid encoding HA-tagged PKC $\varepsilon$-[pcDNA3HA-PKC $\varepsilon$ ] (a gift from Dr. Jae-Won Soh, Inha University Korea) [19]. SH-SY5Y cells were transfected with $400 \mathrm{ng}$ of plasmid with Lipofectamine 2000, according to the manufacturer's instructions and positive clones were selected with $400 \mu \mathrm{g} / \mathrm{ml} \mathrm{G} 418$ (Geneticin). PKC $\varepsilon$ overexpression was detected in western blots with either anti-HA antibody or anti-PKC $\varepsilon$ antibody.

\section{Experimental treatments}

Confluent monolayers of cells were washed twice with PBS and treated at $37^{\circ} \mathrm{C}$ in serum free medium in the presence of vehicle alone or in the presence of the compound of interest. Before treatment, cells were incubated for $20 \mathrm{~min}$ with or without inhibitors; at the end of treatment, the conditioned medium was collected for the analysis of $\mathrm{sA} \beta \mathrm{PP} \alpha$ release by western blot. When the inhibitor peptide of $\mathrm{PKC} \varepsilon$ translocation was used, the cells were pretreated for $2 \mathrm{~h}$ with the inhibitor peptide in presence of PULSin ${ }^{\mathrm{TM}}$ in serum free medium and following rinsing twice with PBS and subject to treatment.

\section{Immunodetection of $s A \beta P P \alpha, P K C \varepsilon$, and tubulin}

Conditioned medium was collected after treatment and centrifuged at $13.000 \times \mathrm{g}$ for $5 \mathrm{~min}$ to remove detached cells and debris. Proteins in the medium were quantitatively precipitated by the deoxycholate/trichloroacetic acid procedure as previously described [12]. Cell monolayers were washed twice with ice cold PBS and lysed on the tissue culture dish by addition of ice-cold lysis buffer $(20 \mathrm{mM}$ Tris/ $\mathrm{HCl}$ $\mathrm{pH} 7.5,150 \mathrm{mM} \mathrm{NaCl}, 2 \mathrm{mM}$ EDTA, $0.2 \mathrm{mM} 4-$ (2-aminoethyl) benzenesulfonyl fluoride hydrochloride (AEBSF), $20 \mu \mathrm{g} / \mathrm{ml}$ leupeptin, $25 \mu \mathrm{g} / \mathrm{ml}$ aprotinin, 0.5 $\mu \mathrm{g} / \mathrm{ml}$ pepstatin $\mathrm{A}$ and $0.5 \%$ Triton $\mathrm{X}-100)$. An aliquot 
of the cell lysate was used for protein analysis with the Pierce Bicinchoninic Acid kit, for protein quantification. Normalization of protein loading on each blot was obtained by loading a volume of sample of conditioned medium standardized to total cell lysate protein concentration. Proteins were subjected to SDSPAGE $(10 \%)$ and then transferred onto PVDF membrane $0.45 \mu \mathrm{m}$ (Immobilon, Millipore Corp, Bedford, MA, USA). The membrane was blocked for $1 \mathrm{~h}$ with $5 \%$ non-fat dry milk in Tris-buffered saline containing $1 \%$ Tween 20 (TBST). Membranes were immunoblotted with the antibody $6 \mathrm{E} 10$ (1:1000 dilution in 5\% non fat dry milk, from Chemicon-Prodotti Gianni, Milano, Italy). The detection was carried out by incubation with horseradish peroxidase conjugated goat antimouse IgG (1:10000 dilution in 5\% non fat dry milk, from Pierce, Rockford, IL, USA) for $1 \mathrm{~h}$. The blots were then washed extensively and $\mathrm{sA} \beta \mathrm{PP} \alpha$ visualized using enhanced chemiluminescent methods (Pierce, Rockford, IL, USA). For the detection of $\mathrm{PKC} \varepsilon$ and tubulin, proteins were measured as described earlier, diluted in sample buffer (62.5 mM Tris/ $\mathrm{HCl}$ pH 6.8, $2 \%$ SDS, $10 \%$ glycerol, $50 \mathrm{mM}$ dithiothreitol, $0.1 \%$ Bromophenol blue) and subjected to Western blot analysis with the method indicated previously using the mouse anti-human $\mathrm{PKC} \varepsilon$ monoclonal antibody $(1: 10000$ dilution in $5 \%$ non fat dry milk, from BD biosciences, Erembodegem, Belgium) or the mouse anti $\alpha$-tubulin, clone DM1A, monoclonal antibody (at 1:5000 dilution in 5\% non fat dry milk, from Sigma Chemical Co., St. Louis, MO,USA).

\section{Co-immunoprecipitation}

The cells were washed twice with PBS, and treated with $100 \mu \mathrm{M} \mathrm{CCh}$ in serum free medium, or serum free medium alone, for 10 and $20 \mathrm{~min}$ at $37^{\circ} \mathrm{C}$. Cells were washed twice with cold PBS and lysed in immunoprecipitation buffer (10 mM Tris- $\mathrm{HCl}$ (pH 7.6), $138 \mathrm{mM}$ $\mathrm{NaCl}, 0.5 \%$ Nonidet P40, $0.2 \mathrm{mM}$ AEBSF, $20 \mu \mathrm{g} / \mathrm{ml}$ leupeptin, $25 \mu \mathrm{g} / \mathrm{ml}$ aprotinin, $0.5 \mu \mathrm{g} / \mathrm{ml}$ pepstatin $\mathrm{A}$, $1 \mathrm{mM} \mathrm{NaF}$ ). Lysed cells were sonicated twice at $40 \mathrm{~Hz}$ for $10 \mathrm{~s}$, and centrifuged at $12.000 \times \mathrm{g}$ at $4{ }^{\circ} \mathrm{C}$ for 10 min. The detergent-soluble material (supernatant) was precleared by incubation with $20 \mu \mathrm{l}$ of protein AG Plus agarose (Santa Cruz Biotechnology) for $1 \mathrm{~h}$ at $4{ }^{\circ} \mathrm{C}$. The samples were centrifuged at $3.000 \times \mathrm{g}$ at $4{ }^{\circ} \mathrm{C}$ for 2 $\mathrm{min}$, and protein quantity was determined using BCA reagent (Pierce). Immunoprecipitation was performed with $1 \mu \mathrm{g}$ of mouse anti-human CK2 $\alpha$ monoclonal antibody (Chemicon, Prodotti Gianni, Milano, Italy), to- gether with approximately $0.5-1 \mathrm{mg}$ of protein diluted in the immunoprecipitation buffer to a total volume of $500 \mu \mathrm{l}$. After overnight incubation at $4{ }^{\circ} \mathrm{C}$, immunocomplexes were collected by using protein AG Plus agarose, incubated at $4{ }^{\circ} \mathrm{C}$ for $1 \mathrm{~h}$ and subsequently washed three times with immunoprecipitation buffer. Immunoprecipitated CK2 was recovered by resuspending the pellets in sample buffer. PKC $\varepsilon$ was detected using the mouse anti-human $\mathrm{PKC} \varepsilon$ monoclonal antibody at a 1:1000 dilution (BD bioscences, Erembodegem, Belgium).

\section{Immunocytochemical analysis of PKC and CK2 co-localization}

SH-SY5Y neuroblastoma cells were seeded on glass coverslips at a density of $1 \times 10^{5}$ viable cells per well in a 24-well plate. Cells on coverslips were treated with carbachol $100 \mu \mathrm{M}$ in serum free medium for $20 \mathrm{~min}$, whereas control cells were incubated with medium alone for $20 \mathrm{~min}$; when indicated TBB was added 20 min prior to the treatment. After treatment, cells were fixed in ethanol $70 \%$ at $-20^{\circ} \mathrm{C}$, washed with PBS and permeabilized for $15 \mathrm{~min}$ at room temperature with $0.01 \%$ Triton X-100 in PBS. Nonspecific bindings with $\mathrm{PKC} \varepsilon$ and CK2 were blocked by incubation for $30 \mathrm{~min}$ with PBS containing 1\% BSA. Cells were incubated for $1 \mathrm{~h}$ with the rabbit antibody specific for $\mathrm{PKC} \varepsilon$ (Santa Cruz Biotechnology Inc., CA, USA) diluted 1:50 in $\mathrm{PBS} / 1 \%$ BSA solution. After rinsing in PBS, a FITC conjugated rabbit anti-IgG antibody (Invitrogen, CA, USA) was diluted at 1:500 in PBS/1\% BSA to detect $\mathrm{PKC} \varepsilon$. Cells were then subjected to a further incubation for $1 \mathrm{~h}$ with a monoclonal antibody specific for CK2 (Millipore, MA, USA) diluted 1:20 in PBS/1\% BSA solution. To detect CK2 cells were incubated for $1 \mathrm{~h}$ at room temperature with an anti-mouse IgG antibody conjugated with ALEXA 633 (Invitrogen, CA, USA) diluted 1:50 in PBS/1\% BSA. After the fluorescent labeling procedures, cells were finally counterstained for DNA for $5 \mathrm{~min}$ with a $0.1 \mu \mathrm{g} / \mathrm{ml}$ HOECST 33342 solution in PBS, and mounted upside down on glass slides, in a drop of Mowiol (Calbiochem). Images were obtained with a confocal microscope Leica DM IRBE with Leica TCS SP software.

\section{Immunodetection of ADAM10 and TACE/ADAM17}

Following $2 \mathrm{~h}$ of $100 \mu \mathrm{M}$ CCh treatment in the presence or absence of $16 \mu \mathrm{M}$ TBB, cell monolayers were washed twice with ice cold PBS and lysed on the tissue 
culture dish by addition of ice-cold lysis buffer $20 \mathrm{mM}$ Tris/ $\mathrm{HCl} \mathrm{pH} \mathrm{7.4,} \mathrm{0.32} \mathrm{M} \mathrm{sucrose,} 2$ mM EDTA, $0.5 \mathrm{mM}$ EGTA, $50 \mathrm{mM} \beta$-mercaptoethanol, $0.2 \mathrm{mM}$ AEBSF, $20 \mu \mathrm{g} / \mathrm{ml}$ leupeptin, $25 \mu \mathrm{g} / \mathrm{ml}$ aprotinin and $0.5 \mu \mathrm{g} / \mathrm{ml}$ pepstatin A. Cell lysis was achieved using a Dounce homogenizer (15-20 strokes were performed for each sample). Cell lysates were centrifuged at 3,000 $\times \mathrm{g}$, for $5 \mathrm{~min}$ at $4^{\circ} \mathrm{C}$, and the surnatants were separated from the pellets (nuclei), and were further pelleted by centrifugation for $60 \mathrm{~min}$ at $4{ }^{\circ} \mathrm{C}$ and $100,000 \times \mathrm{g}$. The resulting pellet (referred to here as the particulate fraction) was resuspended in lysis buffer $20 \mathrm{mM}$ Tris/ $\mathrm{HCl}$ pH 7.5, $150 \mathrm{mM} \mathrm{NaCl}, 2 \mathrm{mM}$ EDTA, $0.2 \mathrm{mM}$ AEB$\mathrm{SF}, 20 \mu \mathrm{g} / \mathrm{ml}$ leupeptin, $25 \mu \mathrm{g} / \mathrm{ml}$ aprotinin, $0.5 \mu \mathrm{g} / \mathrm{ml}$ pepstatin $\mathrm{A}$, and $0.5 \%$ Triton $\mathrm{X}-100$ and an aliquot was used for protein analysis with the Pierce Bicincronic Acid kit, for protein quantification. Subsequently it was diluted in sample buffer $(62.5 \mathrm{mM}$ Tris/ $\mathrm{HCl}$ $\mathrm{pH} 6.8,2 \%$ SDS, $10 \%$ glycerol, $50 \mathrm{mM}$ dithiothreitol, $0.1 \%$ Bromophenol blue) and subjected to Western blot analysis with the method indicated previously, using the mouse anti-ADAM10 monoclonal antibody (1:1000) from Abcam Inc., Cambridge, MA, USA or the goat anti-TACE/ADAM17 polyclonal antibody (1:200), able to detect the C-terminal region of both the precursor and mature TACE/ADAM17, from Santa Cruz Biotechnology Inc., Santa Cruz, California, USA; in both cases tubulin was also performed as a normal control of proteins.

\section{Densitometry and statistics}

Analysis of Western blot images was performed by calculating the relative intensity of the immunoreactive bands after acquisition of the blot image through a Nikon CCD video camera module and analysis by means of the Image 1.47 program (Wayne Rasband, NIH, Research Service Branch, NIMH, Bethesda, MD, USA). The relative densities of the bands were expressed as arbitrary units and normalized to data obtained from control sample run under the same conditions. Controls were processed in parallel with stimulated samples and always included in the same blot. Preliminary experiments with serial dilutions of secreted protein allowed determination of optimal linear range for chemiluminescence reaction. Results are reported as means of three to four independent experiments \pm S.E.M. Statistical analysis was made by oneway analysis of variance followed, when significant, by the multiple comparison Bonferroni test; $p<0.05$ was considered significant.

\section{RESULTS AND DISCUSSION}

\section{$P K C \varepsilon$ and the processing of $A \beta P P$}

We produced a stable clone of SH-SY5Y neuroblastoma cells overexpressing $\mathrm{PKC} \varepsilon$. The clone (W3) expresses higher levels of $\mathrm{PKC} \varepsilon$ determined by western blot (Fig. 1A) and real time PCR (not shown). The overexpressing cells were subjected to a treatment with $100 \mu \mathrm{M}$ of $\mathrm{CCh}$ in serum free medium for $2 \mathrm{~h}$ and $\mathrm{sA} \beta \mathrm{PP} \alpha$ release was detected by western blot in the conditioned medium. PKC $\varepsilon$ overexpressing cells, as expected, produce a 2 -fold increase in $\mathrm{sA} \beta \mathrm{PP} \alpha$ release compared to stimulated wild type cells (Fig. 1B). These data are all in agreement and sustain our previous findings obtained in $\mathrm{PKC} \varepsilon$ antisense downregulated cells [13], indicating that the main PKC isoform involved in the downstream events following carbachol stimulation is PKC $\varepsilon$. Other authors also suggested that $\mathrm{PKC} \varepsilon$ participates in $\mathrm{A} \beta \mathrm{PP} \alpha$-secretase processing [20-22], and the fact that some PKC isoforms, namely $\mathrm{PKC} \alpha$, are involved mostly in constitutive $\mathrm{A} \beta \mathrm{PP}$ processing [23], indicate that the multiple isoforms of PKC may be selectively involved in different aspects of $\mathrm{A} \beta \mathrm{PP}$ processing.

We further explored the involvement of $\mathrm{PKC} \varepsilon$ using a specific inhibitor, namely an inhibitor peptide mimicking the $\mathrm{V} 1$ region of $\mathrm{PKC} \varepsilon$, which interacts with the Receptor for Activated C Kinase 2 (RACK2) [24,25], in order to block the translocation of $\mathrm{PKC} \varepsilon$ following cholinergic stimulation. The peptide is not cell permeable [25], therefore the cells were pretreated for $2 \mathrm{~h}$ with $5 \mu \mathrm{M}$ of inhibitor peptide using PULSin as delivering agent; following incubation, the cells were washed with phosphate buffer and subjected to the treatment, adding medium without serum or with $100 \mu \mathrm{M} \mathrm{CCh}$ in serum free medium for $2 \mathrm{~h}$. The effect of the addition of $\mathrm{PKC} \varepsilon$ inhibitor peptide was a decrease of about $40 \%$ in $\mathrm{sA} \beta \mathrm{PP} \alpha$ release compared to untreated cells (Fig. 1C) suggesting that $\mathrm{PKC} \varepsilon$ translocation is necessary for $\mathrm{sA} \beta \mathrm{PP} \alpha$ release. Since we used a membrane permeating agent, the proper controls were included in our protocol, however, no significant effect on $\mathrm{sA} \beta \mathrm{PP} \alpha$ release was detected (data not shown). Overall these data reinforce and confirm the involvement of PKC $\varepsilon$ in carbachol stimulated $\mathrm{A} \beta \mathrm{PP}$ processing [13]. In addition since the sequence of the inhibitor peptide is identical to the $\mathrm{V} 1$ region of $\mathrm{PKC} \varepsilon$, which is the domain of interaction with RACK2 [24,25], the data suggest that the anchoring protein is involved in $\mathrm{PKC} \varepsilon$ translocation following cholinergic stimulation. The observation that 

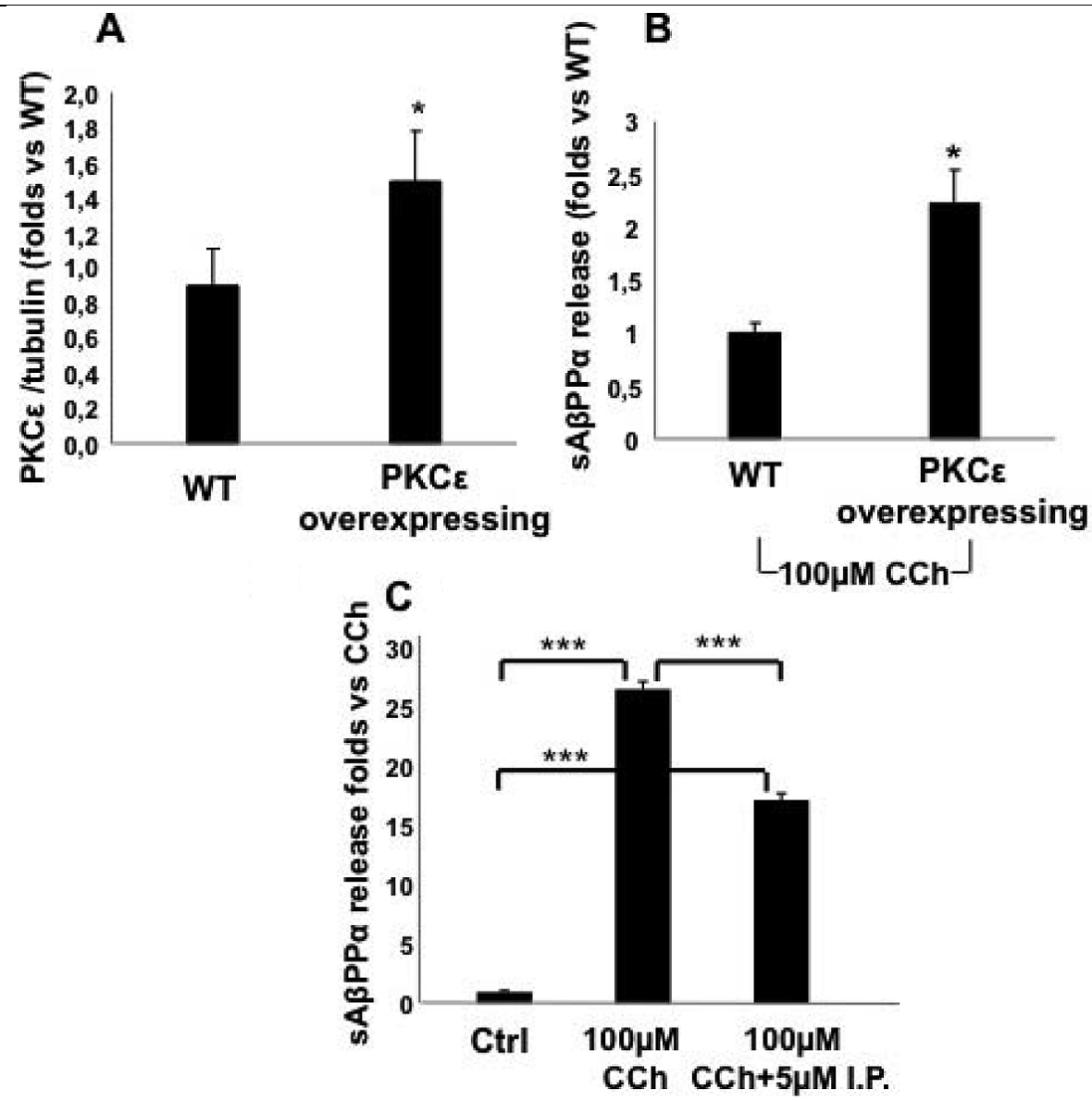

Fig. 1. A) Stably transfected SH-SY5Y cells show PKC $\varepsilon$ expression level about 1.6 fold higher than corresponding wild type cells. The clone characterization was achieved by western blotting (quantitation shown in figure) and RT-PCR (not shown) evaluating the presence of both the endogenous and esogenous form of PKC $\varepsilon$. B) The overexpression of PKC $\varepsilon$ in the SH-SY5Y cells induces an increase in $\mathrm{sA} \beta \mathrm{PP} \alpha$ release about 2-fold higher than the corresponding wild type cells, in cholinergic stimulus condition upon treatment with $100 \mu \mathrm{M} \mathrm{CCh}$ for $2 \mathrm{~h}$. C) Blocking the translocation of $\mathrm{PKC} \varepsilon$ with the inhibitor peptide (IP) reduces $\mathrm{sA} \beta \mathrm{PP} \alpha$ release after carbachol treatment. Cells have been treated with 100 $\mu \mathrm{M}$ CCh for $2 \mathrm{~h}$ in presence or absence of $5 \mu \mathrm{M}$ IP (added $2 \mathrm{~h}$ before). $* p<0.05$; ${ }^{* * *} p<0.001$ (Bonferroni Multiple Comparison Test).

the decrease in $\mathrm{sA} \beta \mathrm{PP} \alpha$ release was greatly reduced by the peptide inhibitor but did not fully return to basal secretion suggests that other additional mechanisms of signal transduction may be involved.

\section{CK2 participation in $A \beta P P$ processing}

As suggested by some authors [16-18], we addressed the issue of a close relationship between the activity of CK 2 and $\mathrm{PKC} \varepsilon$. First of all we performed a set of experiments using TBB (4,5,6,7-tetrabromobenzotriazole), a specific inhibitor of $\mathrm{CK} 2$ which has been recommended in cell-based assays [26] and observed that treatment of SH-SY5Y cells with $16 \mu \mathrm{M}$ TBB prior to treatment with $100 \mu \mathrm{M} \mathrm{CCh}$, reduces stimulated $\mathrm{s} \beta \mathrm{PP} \alpha$ release by $60 \%$ (Fig. 2). Interestingly, treatment with TBB also induced an inhibition in the basal release of $\mathrm{sA} \beta \mathrm{PP} \alpha$ (Fig. 2). Various TBB concentrations were assayed, leading to the choice of the $16 \mu \mathrm{M}$ concentration, showing consistent effect on $\mathrm{sA} \beta \mathrm{PP} \alpha$ release without significant effects on cell viability (MTT assays-not shown).

These initial results suggested an involvement of CK2 in the pathway leading to $\alpha$-secretase activation following $\mathrm{PKC} \varepsilon$ stimulation by cholinergic receptor agonists.

To test the hypothesis of a direct interaction between $\mathrm{CK} 2$ and $\mathrm{PKC} \varepsilon$, we set up an experiment in which, following a treatment with $100 \mu \mathrm{M} \mathrm{CCh}$ for 10 and 20 min, cell lysates were subjected to immunoprecipitation with anti-CK2 antibody. Using an immunoprecipitating antibody mouse anti-human alpha CK2 subunit, followed by western blot for $\mathrm{PKC} \varepsilon$, revealed that 

S.C. Lenzken et al. / Recruitment of Casein Kinase 2 is Involved in AßPP Processing Following Cholinergic Stimulation

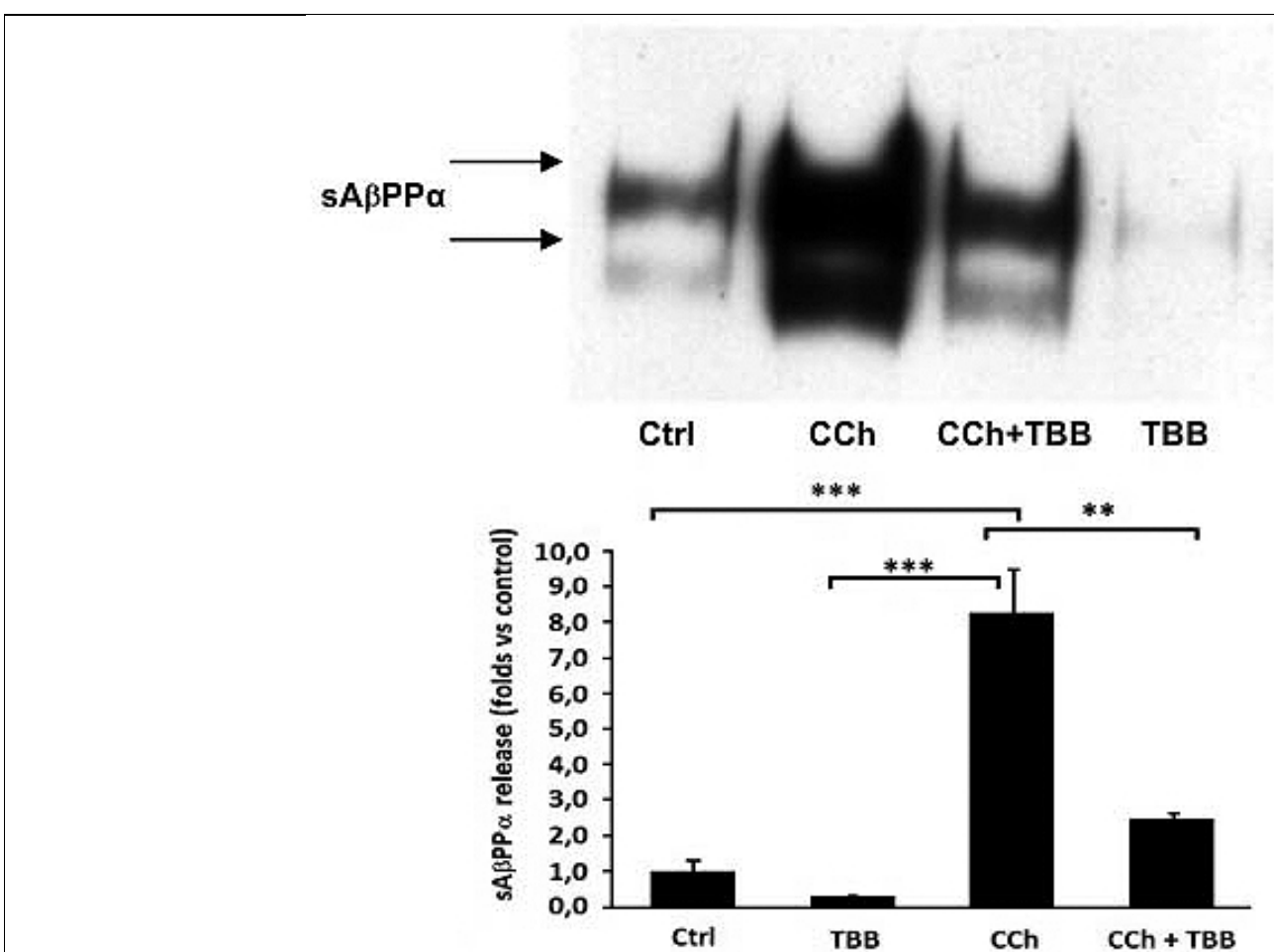

Fig. 2. Inhibition of $\mathrm{CK} 2$ with $\mathrm{TBB}$ reduces the cholinergic stimulated release of $\mathrm{sA} \beta \mathrm{PP} \alpha$. SH-SY5Y cells release $\mathrm{sA} \beta \mathrm{PP} \alpha$ as a doublet corresponding to the $\mathrm{A} \beta \mathrm{PP}$ isoforms expressed by the cells [12]. Cells have been pretreated with $16 \mu \mathrm{M} \mathrm{TBB}$ (see methods for details) for $30 \mathrm{~min}$ and then treated with $100 \mu \mathrm{M} \mathrm{CCh}$ for $2 \mathrm{~h}$. The effect of TBB is an almost complete inhibition of stimulated sA $\beta \mathrm{PP} \alpha$ release, returning levels of secretion almost to control levels. We have observed also a reduction of basal $\mathrm{sA} \beta \mathrm{PP} \alpha$ secretion which however does not reach statistical significance. ${ }^{* *} p<0.01 ; * * * p<0.001$ (Bonferroni Multiple Comparison Test).

the two proteins are co-immunoprecipitated with a significant $\mathrm{PKC} \varepsilon$ band present already at $10 \mathrm{~min}$ and increasing further after $20 \mathrm{~min}$ of CCh treatment (Fig. 3). The data is suggestive of a direct interaction between $\mathrm{CK} 2$ and $\mathrm{PKC} \varepsilon$ that takes place immediately after the application of $\mathrm{CCh}$. The interaction between $\mathrm{PKC} \varepsilon$ and CK2 was also confirmed by immunocytochemical experiments. As shown in Fig. 4, in basal conditions (Ctrl) CK2 and PKC $\varepsilon$ are diffusely distributed at a cellular level, whereas after treatment with $100 \mu \mathrm{M} \mathrm{CCh}$ for $20 \mathrm{~min}$, the two proteins are both localized near the nucleus. This is further supports several reports that suggest a clear functional relationship between PKC $\varepsilon$ and CK2; for example, Sanghera and coworkers found that PKCs from a brain homogenate were able to increase the CK2 activity in vitro [16], whilst Boehring and colleagues recently reported a similar increase on CK2 activity after phorbol ester stimulation in hippocampal neurons [18].

We wanted to investigate whether the activity of CK2 related to $\mathrm{A} \beta \mathrm{PP}$ processing was located upstream or downstream of PKC in our cellular model. Silva-Neto

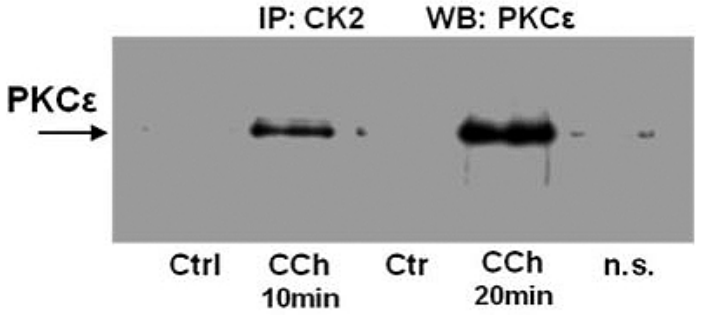

Fig. 3. Co-immunoprecipitation analysis. In order to establish if the two kinases directly interact, a co-immunoprecipitation assay has been performed using as immunoprecipitating antibody mouse ant $\mathrm{CK} 2 \alpha$, then mouse anti $\mathrm{PKC} \varepsilon$ for western blot.

and coworkers suggested that CK2 activity could be located downstream of PKC [17]. Previously, our group showed that after a cholinergic stimulus, $\mathrm{PKC} \varepsilon$ translocates from the cytosol to Golgi-like structure [13]. We treated cells with $100 \mu \mathrm{M} \mathrm{CCh}$ for $20 \mathrm{~min}$ in presence or absence of $16 \mu \mathrm{M}$ TBB. After treatment, the cells were fixed and immunolocalization of $\mathrm{PKC} \varepsilon$ was performed, in order to observe the re-localization of this kinase after treatment with $\mathrm{CCh}$. Accordingly with previous results, in unstimulated conditions $\mathrm{PKC} \varepsilon$ was distribut- 


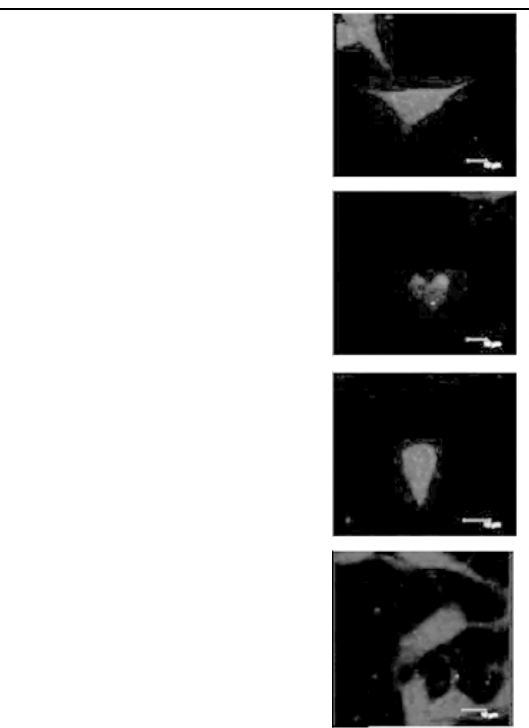

CK2
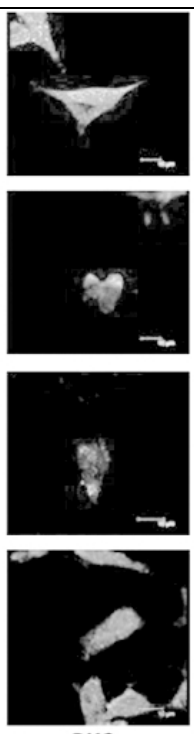

PKC
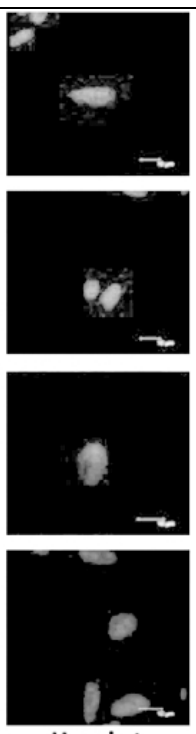

Hoechst
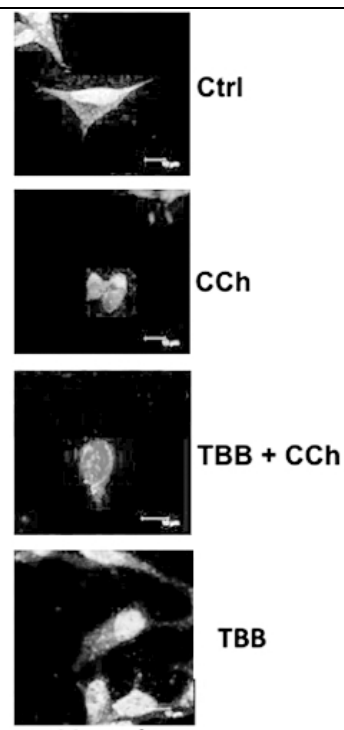

Merged

Fig. 4. Immunolocalization of $\mathrm{PKC} \varepsilon$ and $\mathrm{CK} 2$. In basal conditions $\mathrm{PKC} \varepsilon$, marked in green by FITC conjugated polyclonal antibody, and $\mathrm{CK} 2$, marked in red by ALEXA 633 conjugated monoclonal antibody, are localized diffusely at a cellular level (panel CTRL). After $100 \mu \mathrm{M}$ CCh treatment for $20 \mathrm{~min}, \mathrm{PKC} \varepsilon$ and CK2 colocalize in Golgi-like structures. Pretreatment with $16 \mu \mathrm{M}$ TBB for 20 min followed by $100 \mu \mathrm{M}$ CCh specifically inhibited CK2 translocation, without affecting $\mathrm{PCK} \varepsilon$ subcellular localization in Golgi-like structure (panel TBB $+\mathrm{CCh}$ ). Treatment with only $16 \mu \mathrm{M}$ TBB for 20 min does not alter the diffuse distribution of both PKC $\varepsilon$ and CK2 similar to basal condition (panel TBB). Confocal image, magnification: 63x. (Colours are visible in the electronic version of the article at www.iospress.nl.)

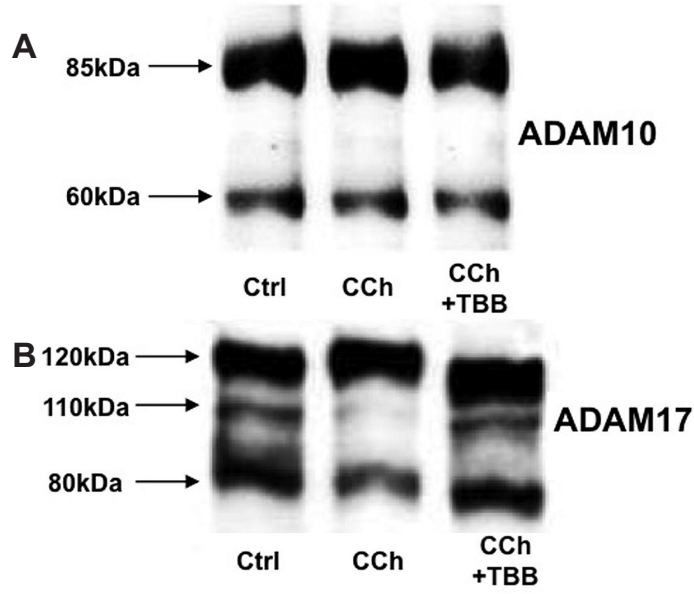

Fig. 5. ADAM10 and ADAM17 profiles after cholinergic stimulation. Western blots have been performed to detect and evaluate the pattern of expression of the two principal putative $\alpha$-secretase, ADAM10, and ADAM17 (TACE). A) The western blot with anti ADAM10 antibodies does not reveal changes in the pattern of the mature and immature form of the protease during $\mathrm{CCh}$ challenge both in the presence or absence of TBB. B) Western blots of ADAM17 show that the addition of $\mathrm{CCh}$ induces a significant modification of the pattern of proteins which is abolished by the treatment with TBB.

ed rather uniformly in the cytosol (Ctrl); whereas, following cholinergic stimulation, the kinase translocated to perinuclear Golgi-like structures. Pretreatment with the specific inhibitor of CK2, TBB, did not affect PKC $\varepsilon$ activation and translocation, thus suggesting that CK2 could be involved downstream of PKC $\varepsilon$ (Fig. 4) in the $\mathrm{CCh}$ stimulated $\mathrm{A} \beta \mathrm{PP}$ processing pathway.

\section{ADAM10 and ADAM17 profiles after cholinergic stimulation}

The proteases ADAM10 and ADAM 17 (TACE) are the most important and best characterized activities known as $\alpha$-secretases [3-5]. While TACE/ADAM17 seems to be involved only in the regulated release of sA $\beta \mathrm{PP} \alpha$ [3], ADAM10 appears to be affecting both the regulated and constitutive processing of $\mathrm{A} \beta \mathrm{PP}[4$, 5]. We investigated whether the pattern of maturation and distribution of ADAM 10 and ADAM 17 was affected during $\mathrm{CCh}$ challenge. Consistent with previous reports [27], we did not observe modification of the protein pattern of ADAM 10 after CCh treatment (Fig. 5A). We have, however, observed a modification of the protein profile of ADAM17 after challenge with CCh (Fig. 5B). Similarly to the pattern described by Alfa Cissè et al. [28], CCh decreased the appearance of a band that may be ascribed to an active state of ADAM17 as suggested to occur following cholinergic stimulation. Pretreatment with TBB, the specific in- 


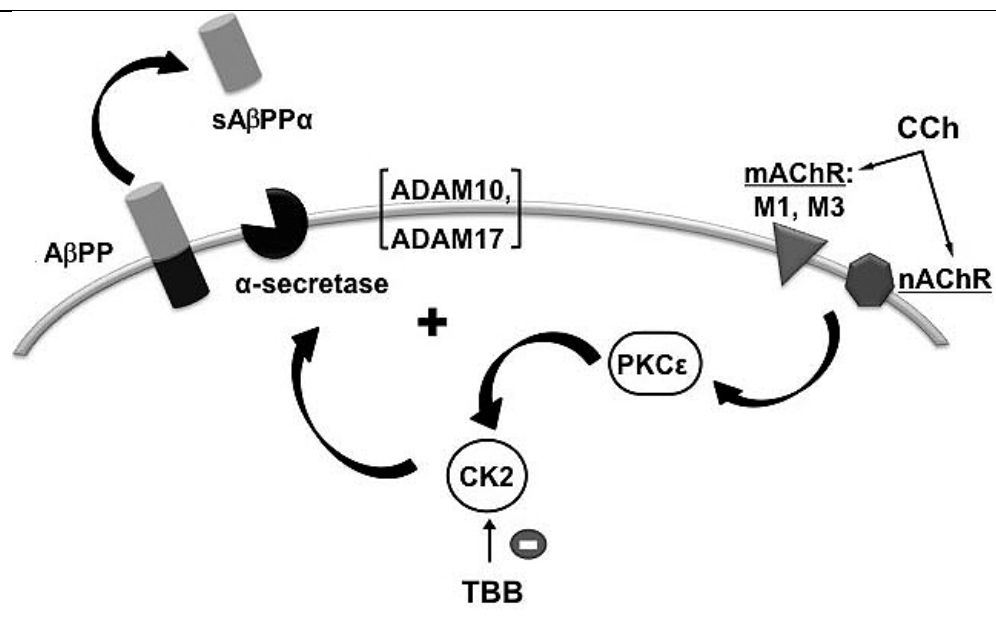

Fig. 6. Schematic pathway of $\mathrm{CK} 2$ involvement in $\mathrm{A} \beta \mathrm{PP}$ processing downstream of cholinergic stimulation. Carbachol stimulates $\mathrm{M} 1$ and $\mathrm{M} \beta$ muscarinic receptors $(\mathrm{mAChR})$ and the nicotinic receptor ( $\mathrm{nAChR}$ ) activating $\mathrm{PKC} \varepsilon$ which in turn interacts with $\mathrm{CK} 2$. This signaling cascade results in $\mathrm{AA} \beta \mathrm{PP} \alpha$ release after the $\mathrm{A} \beta \mathrm{PP}$ proteolityc cleavage by ADAM10 and especially by ADAM 17 as a consequence of their activation by CK2.

hibitor of CK2, abolished the capability of CCh to modulate the profile of ADAM17 (Fig. 5B). It is possible to speculate that the pattern expressed by ADAM17 is derived from the involvement of pro-protein convertates such as furin, which has been suggested to be one of the proteolytic activator of ADAMs [29]. Moreover other authors identified in the structure of furin a consensus sequence for CK2 phosphorylation [30], an event that can occur in vivo [31]. We cannot rule out the possibility that the evidence described for the involvement of $\mathrm{CK} 2$ in the regulated processing of $\mathrm{A} \beta \mathrm{PP}$ depends on one or more of these mechanisms.

Overall, our data suggest that the stimulation of cholinergic receptors by carbachol leads to regulated $\mathrm{A} \beta \mathrm{PP}$ processing and release of $\mathrm{s} A \mathrm{PP} \alpha$, through the activation of a signaling cascade that involves specifically $\mathrm{PKC} \varepsilon$ which in turn interacts with $\mathrm{CK} 2$ and leads to activation of ADAM17 (as the main $\alpha$ secretase involved) (Fig. 6).

\section{ACKNOWLEDGMENTS}

We are grateful to Dr. Jae-Won Soh for providing the PKC $\varepsilon$ construct and to Dr. Meggio and Dr. Sarno for helpful discussion. We gratefully acknowledge funding from the Italian MIUR - 2005051707 to SG, CARIPLO to M.R.; FDL was recipient of a fellowship from CARIPLO.

Authors' disclosures available online (http://www.jalz.com/disclosures/view.php?id=320).

\section{REFERENCES}

[1] Hardy J, Selkoe DJ (2002) The amyloid hypothesis of Alzheimer's disease: progress and problems on the road to therapeutics. Science 297, 353-356.

[2] Verdile G, Fuller S, Atwood CS, Laws SM, Gandy SE, Martins RN (2004) The role of beta amyloid in Alzheimer's disease: still a cause of everything or the only one who got caught? Pharmacol Res 50, 397-409.

[3] Buxbaum JD, Liu KN, Luo Y, Slack JL, Stocking KL, Peschon JJ, Johnson RS, Castner BJ, Cerretti DP, Black RA (1998) Evidence that tumor necrosis factor alpha converting enzyme is involved in regulated alpha-secretase cleavage of the Alzheimer amyloid protein precursor. J Biol Chem 273, 27765-27767.

[4] Lammich S, Kojro E, Postina R, Gilbert S, Pfeiffer R, Jasionowski M, Haass C, Fahrenholz F (1999) Constitutive and regulated alpha secretase cleavage of Alzheimer's amyloid precursor protein by a disintegrin metalloprotease. Proc Nat Acad Sci U S A 96, 3922-3927.

[5] Skovronsky DM, Moore DB, Milla ME, Doms RW, Lee VM (2000) Protein kinase C-dependent alpha-secretase competes with beta-secretase for cleavage of amyloid-beta precursor protein in the trans-golgi network. J Biol Chem 275, 2568 2575.

[6] Tousseyn T, Thathiah A, Jorissen E, Raemaekers T, Konietzko U, Reiss K, Maes E, Snellinx A, Serneels L, Nyabi O, Annaert W, Saftig P, Hartmann D, De Strooper B (2009) ADAM10, the rate-limiting protease of regulated intramembrane proteolysis of Notch and other proteins, is processed by ADAMS9, ADAMS-15, and the gamma-secretase. J Biol Chem 17, 11738-11747.

[7] Racchi M, Govoni S (1999) Rationalizing a pharmacologica intervention on the amyloid precursor protein metabolism. Trends Pharmacol Sci 20, 418-423.

[8] Racchi M, Govoni S (2003) The pharmacology of amyloid precursor protein processing. Exp Gerontol 38, 145-157.

[9] Nitsch RM, Slack BE, Wurtman RJ, Growdon JH (1992) Release of Alzheimer amyloid precursor derivatives stimulated 
by activation of muscarinic acetylcholine receptors. Science 258, 304-307.

[10] Racchi M, Mazzucchelli M, Porrello E, Lanni C, Govoni S (2004) Acetylcholinesterase inhibitors: novel activities of old molecules. Pharmacol Res 50, 441-451.

[11] Lahiri DK, Rogers JT, Greig NH, Sambamurti K (2004) Rationale for the development of cholinesterase inhibitors as antiAlzheimer agents. Curr Pharm Des 10, 3111-3119.

[12] Pakaski M, Kasa P (2003) Role of acetylcholinesterase inhibitors in the metabolism of amyloid precursor protein. Curr Drug Targets CNS Neurol Disord 2, 163-171.

[13] Lanni C, Mazzucchelli M, Porrello E, Govoni S, Racchi M (2004) Differential involvement of protein kinase $\mathrm{C}$ alpha and epsilon in the regulated secretion of soluble amyloid precursor protein. Eur J Biochem 271, 3068-3075.

[14] Meggio F, Pinna L (2003) One-thousand-and-one substrates of protein kinase CK2? FASEB J 17, 349-368.

[15] Blanquet PR (2000) Casein kinase 2 as a potentially important enzyme in the nervous system. Prog Neurobiol 60, 211-246.

[16] Sanghera JS, Charlton LA, Paddon HB, Pelech SL (1992) Purification and characterization of echinoderm casein kinase II - Regulation by protein kinase C. Biochem J 283, 829-837.

[17] Silva-Neto MA, Carneiro AB, Vieira DP, Mesquita RD, Lopes $\mathrm{AH}$ (2002) Platelet-activating factor (PAF) activates casein kinase 2 in the protozoan parasite Herpetomonas muscarum muscarum. Biochem Biophys Res Comm 293, 1358-1363.

[18] Boehning D, Moon C, Sharma S, Hurt KJ, Hester LD, Ronnett GV, Shugar D, Snyder SH (2003) Carbon monoxide neurotransmission activated by CK2 phosphorylation of heme oxygenase-2. Neuron 40, 129-137.

[19] Soh JW, Lee EH, Prywes R, Weinstein IB (1999) Novel roles of specific isoforms of protein kinase $\mathrm{C}$ in activation of the c-fos serum response element. Mol Cell Biol 19, 1313-1324.

[20] Kinouchi T, Sorimachi H, Maruyama K, Mizuno K, Ohno S, Ishiura S, Suzuki K (1995) Conventional protein kinase C (PKC)-alpha and novel PKC epsilon, but not -delta, increase the secretion of an N-terminal fragment of Alzheimer's disease amyloid precursor protein from PKC cDNA transfected 3Y1 fibroblasts. FEBS Lett 364, 203-206.

[21] Yeon SW, Jung MW, Ha MJ, Kim SU, Huh K, Savage MJ, Masliah E, Mook-Jung I (2001) Blockade of PKC epsilon activation attenuates phorbol ester-induced increase of alphasecretase-derived secreted form of amyloid precursor protein.
Biochem Biophys Res Commun 280, 782-787.

[22] Zhu G, Wang D, Lin YH, McMahon T, Koo EH, Messing RO (2001) Protein kinase $\mathrm{C}$ epsilon suppresses Abeta production and promotes activation of alpha-secretase. Biochem Biophys Res Commun 285, 997-1006.

[23] Racchi M, Mazzucchelli M, Pascale A, Sironi M, Govoni S (2003) Role of protein kinase Calpha in the regulated secretion of the amyloid precursor protein. Mol Psychiatry 8, 209-216.

[24] Csukai M, Chen CH, De Matteis MA, Mochly-Rosen D (1997) The coatomer protein beta'-COP, a selective binding protein (RACK) for protein kinase Cepsilon. J Biol Chem 272, 29200 29206.

[25] Brandman R, Disatnik MH, Churchill E, Mochly-Rosen D (2007) Peptides derived from the $\mathrm{C} 2$ domain of protein Kinase $\mathrm{C}$ epsilon (epsilon PKC) modulate epsilon PKC activity and identify potential protein-protein interaction surfaces. $J$ Biol Chem 282, 4113-4123.

[26] Sarno S, Reddy H, Meggio F, Ruzzene M, Davies SP, DonellaDeana A, Shugar D, Pinna LA (2001) Selectivity of 4,5,6,7tetrabromobenzotriazole, an ATP site-directed inhibitor of protein kinase CK2 ('casein kinase-2'). FEBS Lett 496, 44-48.

[27] Zimmermann M, Gardoni F, Marcello E, Colciaghi F, Borroni B, Padovani A, Cattabeni F, Di Luca M (2004) Acetylcholinesterase inhibitors increase ADAM10 activity by promoting its trafficking in neuroblastoma cell lines. JNeurochem 90, 1489-1499.

[28] Alfa Cisse M, Sunyach C, Slack BE, Fisher A, Vincent B, Checler F (2007) M1 and M3 muscarinic receptors control physiological processing of cellular prion by modulating ADAM17 phosphorylation and activity. $J$ Neurosci 27,4083 4092.

[29] Hwang EM, Kim SK, Sohn JH, Lee JY, Kim Y, Kim YS, Mook-Jung I (2006) Furin is an endogenous regulator of alphasecretase associated APP processing. Biochem Biophys Res Commun 349, 654-659.

[30] Tuazon PT, Traugh JA (1991) Casein kinase I and IImultipotential serine protein kinases: structure, function, and regulation. Adv Second Messenger Phosphoprotein Res 23. 123-164.

[31] Jones BG, Thomas L, Molloy SS, Thulin CD, Fry MD, Walsh KA, Thomas G (1995) Intracellular trafficking of furin is modulated by the phosphorylation state of a casein kinase II site in its cytoplasmic tail. EMBO J 14, 5869-5883. 